\title{
Vrsnoća arhitekture \\ u realizacijama Programa društveno poticane \\ stanogradnje(POS) od 2001. do 2020.
}

\section{The Quality of Architecture}

in the Implementation of the State-Subsidized Housing Construction Programmes(POS)2001-2020 
PREGLEDNI RAD

Primljen: 14.10.2020.

Prihvaćen: 8.1.2021.

DOI: $10.31664 / z u .2020 .107 .07$

APSTRAKT

Program društveno poticane stanogradnje (POS) u dosadašnjem je razdoblju provedbe, od 2001. do 2020., pridonio vrsnoći arhitektonskog oblikovanja ponajviše nizom javnih arhitektonskih natječaja koji su rezultirali kvalitetnim projektima i izvedbama stambenih zgrada te afirmacijom nove generacije hrvatskih arhitekata. Mladim arhitektima dodijeljen je niz prestižnih domaćih i inozemnih nagrada i priznanja, a razina arhitektonske produkcije POS-a dosegnula je zavidan nivo kvalitete i unaprijedila hrvatsku arhitektonsku produkciju. Vrsnoća arhitektonskog oblikovanja nagrađivanih POS-ovih stambenih zgrada očituje se u njihovu uspješnom uklapanju u okruženje oblikovanjem volumena i pročelja, zatim domišljatim koncipiranjem te promišljenom organizacijom zajedničkih prostorija i stanova. POSove stambene zgrade unaprijedile su standard stanovanja i potaknule su afirmaciju područja na kojem su sagrađene. Ipak, nakon početnog uspjeha POS-a, uslijedilo je kvalitativno i kvantitativno zaostajanje u odnosu na dosegnutu vrsnoću arhitekture.

KLJUČNE RIJEČI

Program društveno poticane stanogradnje (POS), stanogradnja, stanovanje, stambeno naselje, stambena zgrada, vrsnoća arhitekture
REVIEW ARTICLE

Received: October 14, 2020

Accepted: January 8, 2021

DOI: 10.31664/zu.2020.107.07

SUMMARY

The most important housing construction programme in Croatia before I99I was the Socially Oriented Housing Construction, the so-called DUSI. It was launched in the mid-I970s, and its starting points and results served as a solid basis and impetus for preparing further housing programmes in Croatia after it achieved state independence in I99I. When developing the StateSubsidized Housing Construction (POS), the initial idea was not only to affirm subsidized housing, but also to build up a social housing policy by relying on the experience of DUSI. The aim was to create and maintain a clear position in all segments of the society, including the state administration and local self-management bodies, that all citizens had the right to affordable housing. All elements of the implementation of POS were based on the provisions of the Law on State-Subsidized Housing Construction, adopted in 200I. All creditworthy candidates were granted the right to purchase POS apartments, but exclusively from the priority lists of the local self-management units.

\section{Borka Bobovec}

Hrvatska akademija znanosti i umjetnosti, Hrvatski muzej arhitekture, Zagreb

/ Croatian Academy of Sciences and Arts, The Croatian Museum of Architecture, Zagreb

\section{Ivan Mlinar}

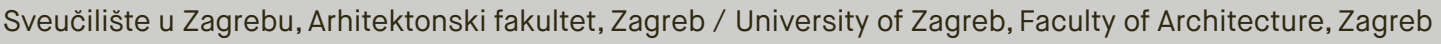

\section{Andriana Pozojević}

Hrvatska akademija znanosti i umjetnosti, Hrvatski muzej arhitekture, Zagreb

/ Croatian Academy of Sciences and Arts, The Croatian Museum of Architecture, Zagreb 
In its take-off phase, POS contributed to the quality of architecture, mostly through a series of architecture and city-planning public design competitions, which resulted in excellent designs and constructions of apartment buildings and the affirmation of a new generation of Croatian architects. The apartment buildings built as part of the POS programme brought to the young architects a number of prestigious national and international awards and acknowledgments, and the high level of architectural production improved Croatian architecture as a whole.

However, this initial success of POS was followed by a period of qualitative and quantitative lag behind the previously achieved excellence. Unfortunately, in 2004 architectural competitions were discontinued and the contracts for architectural designs were now carried out according to the principle of public procurement, which preferred low price over quality. The difference in the quality of constructed buildings is obvious when comparing those built between 2004 and 2007-among which there was still a significant number of those designed and constructed on the basis of design competitions held from 200 I to 2003 , which won professional awards - to those from the later phase of POS, where the number of awards is negligible.

In order to move away from the current trends and mediocrity, it is important to reconsider the whole idea of POS, that is, to bring it back to its original conceptthe construction of high-quality, affordable apartments in good and stimulating living environments, guided by all the relevant parameters. Thereby it is not enough to adhere to the existing legislative framework, but rather to work systematically on the adoption of new guidelines and standards, revising them in the context of the current social situation, which indicates the need to launch new programmes and to adopt a housing strategy in line with other programmatic and strategic documents.

\section{KEYWORDS}

State-Subsidized Housing Construction (POS), housing construction, housing, housing settlement, apartment building, quality of architecture 
UVOD

1

Prvih deset godina POS-a opisano u Bobovec, Mlinar, „Program društveno poticane stanogradnje u Hrvatskoj”, a nastavak u Bobovec, Mlinar, Pozojević, „Programi stanogradnje u Hrvatskoj od I99I. do $2016 "$ ".

2

„POS ide dalje, do 202I. godine tisuću novih stanova”. 3

Špansko, Špansko-Oranice, Vrbani, Vukomerec, Malešnica, Oporovečka i Zapruđe te Novi Jelkovec.

„Smjernice i kriteriji za arhitektonsku vrsnoću građenja”.

„Arhitektonske politike Republike Hrvatske, 20I3.-2020.”
Program društveno poticane stanogradnje (POS) provodi se od 2001. organiziranom izgradnjom stanova, odnosno stambenih zgrada, kako bi se ostvarila svrhovita upotreba javnih i drugih sredstava za pripremu i izgradnju te omogućila prodaja kvalitetnih stanova kreditno sposobnim građanima uz obročnu otplatu po pristupačnijim uvjetima od tržišnih u pogledu kamata i rokova otplate. Javna sredstva kojima se potiče organizirana izgradnja stanova osiguravaju Republika Hrvatska i jedinice lokalne samouprave. POS je trebao u relativno kratkom vremenu riješiti dva iznimno složena zadatka-osigurati dovoljan broj stambenih jedinica na cjelokupnom prostoru države, uz osiguranje kvalitete suvremenog stanovanja i života, kao i očuvanja prostora od nekontrolirane potrošnje neplanskom gradnjom. Ne manje važno bilo je i aktiviranje građevinskog sektora kao jednog od multiplikatora općeg razvitka. Tijekom dva desetljeća kontinuirane provedbe POS-a posebno se ističe početno razdoblje od 2001. do 2003. u kojem je u kratkom vremenu projektiran najveći broj stanova i započeta njihova izgradnja. ${ }^{1}$ Nakon stagnacije početkom druge dekade, novo razdoblje dinamičnije izgradnje kreće sredinom 2019. godine. Prema tadašnjim projekcijama, do 2021. bit će realizirano „novih tisuću stanova" na različitim lokacijama u cijeloj državi. Konačni je rezultat, u razdoblju od 2001. do kraja 2019., 8276 izgrađenih stanova. ${ }^{2}$ Najviše ih je realizirano u Zagrebu, na sedam lokacija, koji ima i najduži kontinuitet u izgradnji POS-ovih stanova-od 2002. do 2016. ${ }^{3}$

Dok dinamika i lokacije planiranih i realiziranih gradnji ukazuju na aktualne društvene, gospodarske i demografske procese, razina urbanističke i arhitektonske kvalitete POS-ovih zgrada i naselja pokazuju ambiciju društva, odnosno značaj koji državne i lokalne vlasti pridaju stanovanju, tj. izgradnji prostora svakodnevnog življenja. Kroz odabrane primjere POS-ovih zgrada i stambenih naselja za koje su raspisivani arhitektonski i urbanističko-arhitektonski natječaji pokazat će se vrsnoća arhitekture. U nastojanju da se proces projektiranja i izgradnje ubrza, odustalo se od provođenja natječaja, što je u nastavku realizacije Programa dovelo do nepovoljnih okolnosti koje su utjecale na arhitektonsku vrsnoću, što nadalje ukazuje na potrebu preispitivanja načina pripreme i provedbe POS-a. Posebna pozornost posvetit će se važnosti i ulozi natječaja kao istinskog promotora transparentnosti i izvrsnosti u arhitektonskoj praksi prilikom planiranja i gradnje suvremenog grada, što se postiže implementacijom visokih standarda oblikovanja i gradnje, kao i novih tehnologija i inovacija. ${ }^{4} \mathrm{U}$ konačnici, osvrt na provedbu POS-a uoči njegove dvadesete obljetnice analizom i valorizacijom ostvarenih rezultata nastoji potaknuti preispitivanje aktualne provedbe i ukazati na potrebu stvaranja sveobuhvatne stambene politike, preporuka, novih pravila i novih načina strukturiranja nužne nacionalne stambene strategije i pratećih stambenih programa, kroz uključivanje relevantnih znanstvenih metoda, umjetničkih vještina i kreativnosti. ${ }^{5}$ 

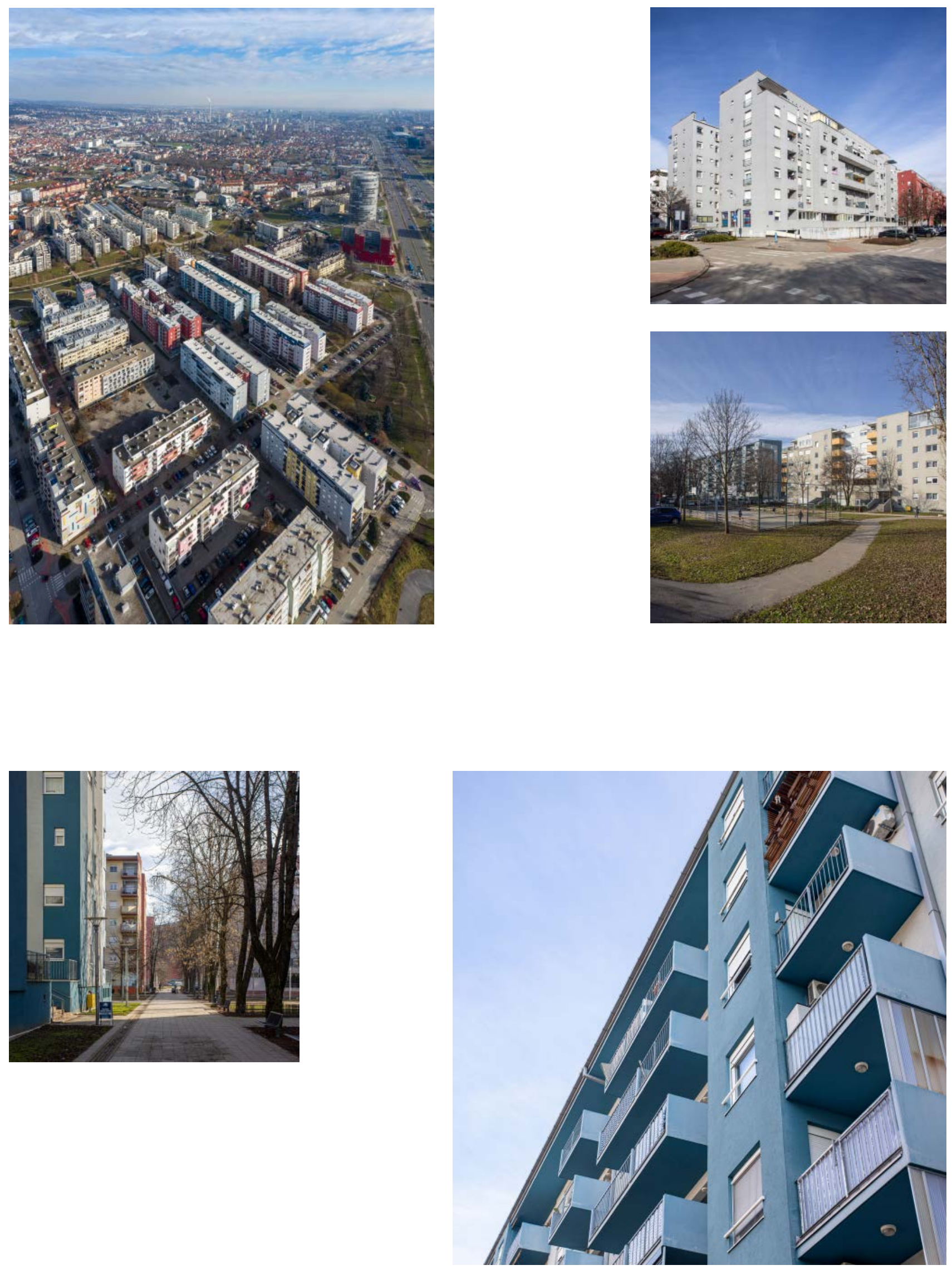


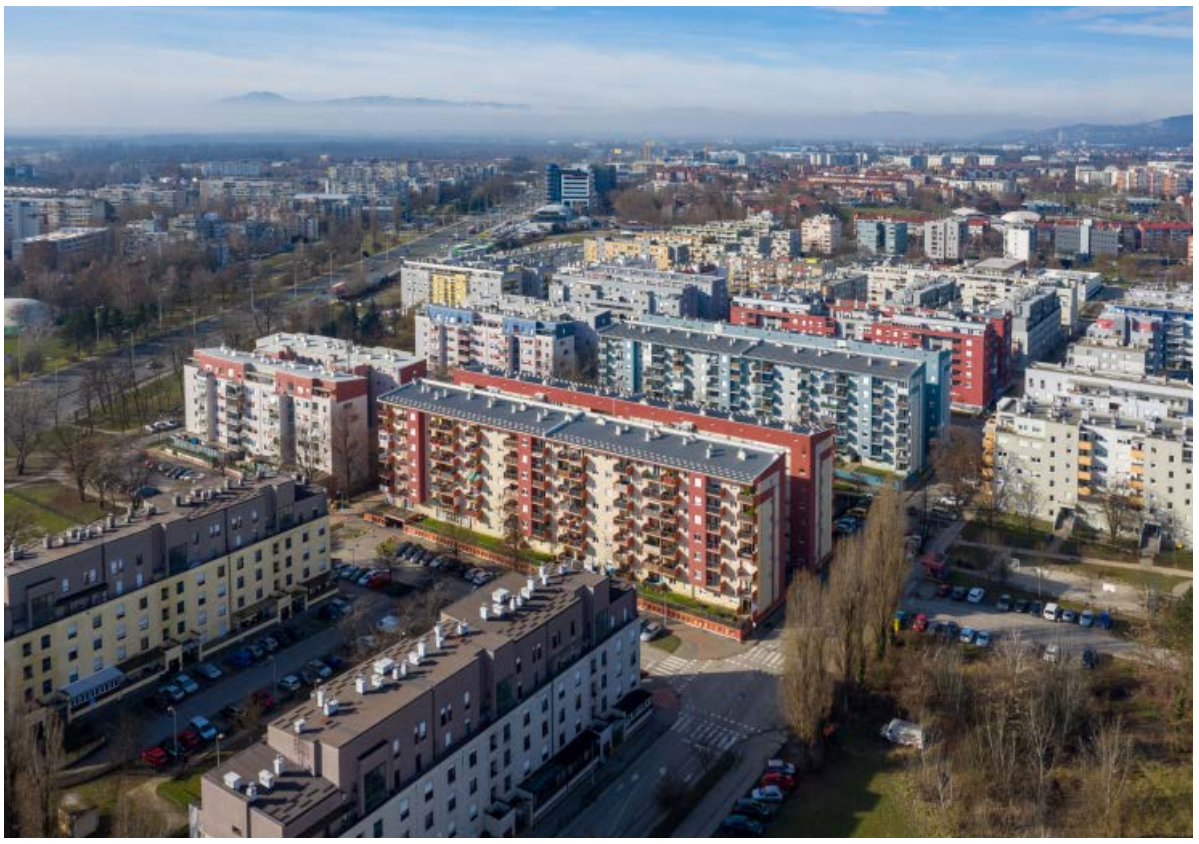

Program društveno poticane stanogradnje (POS) u Španskom u Zagrebu, 2020. Foto: Paolo Mofardin / State-Subsidized Housing Construction (POS) in Špansko in Zagreb, 2020. Photo: Paolo Mofardin $\leftarrow \uparrow \downarrow$
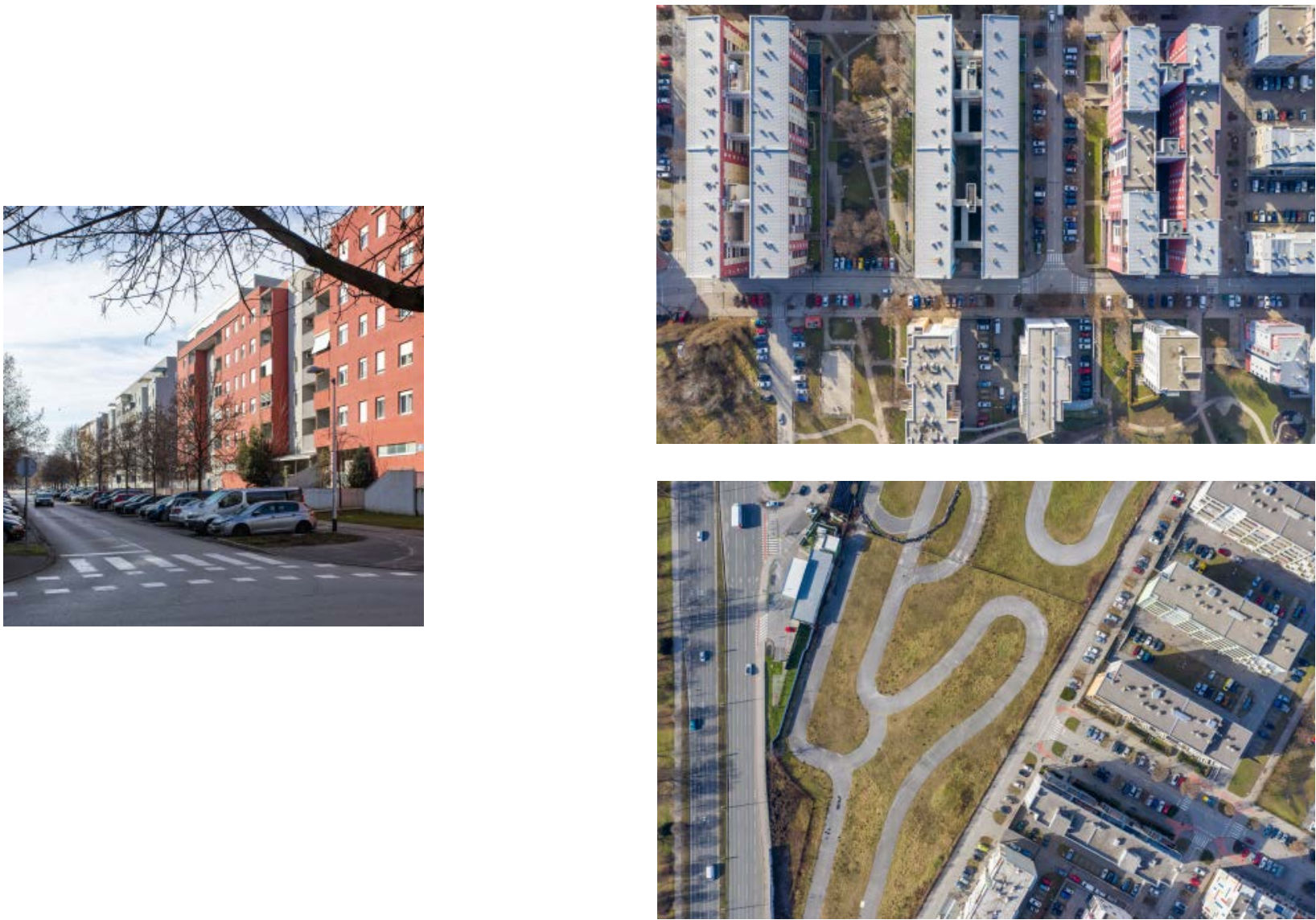


\section{STAMBENI PROGRAMI}

Stanovanje je kao najvažnija sastavnica socijalnog razvoja društva, a posljedično i gospodarskog napretka, regulirano i kontrolirano područje, ne samo po pitanju dostupnosti ostvarivanja prava na stanovanje nego i po pitanju osiguranja osnovnog standarda i kvalitete stanovanja. Istodobno, gradnja za primarno i sekundarno stanovanje ${ }^{6}$ najveći je konzument prostora i glavni sadržaj naselja te joj pripada najveći udio u tržišno motiviranoj gradnji.' Upravo zbog toga stanovanje zaslužuje iznimnu pažnju u planiranju, projektiranju i gradnji, bez obzira na to je li riječ o individualnim, poduzetničkim ili društvenim naporima da se osigura stambeni prostor. Stambena naselja jasne urbanističke prepoznatljivosti, morfološke definiranosti i slojevitosti danas su u većini slučajeva zamijenjena sklopovima koje karakterizira nedostatak javnih sadržaja i površina, društvene infrastrukture tj. nadgradnje, identiteta i karaktera, čija je prvenstvena i često jedina značajka banalna izgrađenost. Stoga je iznimno važno objektivno, sintezno, znanstveno i stručno izrađivati, analizirati i usavršavati programe stanogradnje kao važne teme u kontekstu graditeljstva i prostornoga uređenja Hrvatske.

Korisna površina sagrađenih zgrada u Republici Hrvatskoj, prema posljednjim podacima Državnog zavoda za statistiku, procijenjena je na oko 150 milijuna $\mathrm{m}^{2}$, od čega su stambene zgrade oko $33 \%$, a obiteljske kuće $53 \%$, dok ostatak od svega $14 \%$ čine zgrade javnog i uslužno-proizvodnog sektora. Veći dio ukupnog stambenog fonda, oko $65 \%$ zgrada, sagrađeno je u kontinentalnom dijelu Hrvatske, dok priobalni dio obuhvaća preostalih $35 \%$. Bitna je činjenica da nastanjene obiteljske kuće, kao i stanovi sagrađeni u razdoblju od 1941. do 1987., sudjeluju u ukupnoj površini stambenog fonda s više od $65 \% .^{8}$ Kad ovim brojevima dodamo stambene jedinice sagrađene prije Drugog svjetskog rata i sve to stavimo u kontekst promjene društvenog uređenja početkom devedesetih godina prošlog stoljeća, tj. prodaje društvenih stanova, ${ }^{9}$ dolazimo do činjenice da je u Hrvatskoj 97,3\% nastanjenih stanova u privatnom vlasništvu, a tek je preostalih $2,7 \% \mathrm{u}$ vlasništvu pravnih osoba (države, jedinica lokalne samouprave, trgovačkih društava i sl.). ${ }^{10} \mathrm{U}$ vlastitim stambenim prostorima stanuje čak $89,4 \%$ stanovnika. Istodobno je gotovo u potpunosti izostao državni ili gradski najam stanova, kako je to uobičajeno u zemljama Europske unije koje nisu prolazile tranziciju, tj. promjenu iz socijalističkog u kapitalističko društveno uređenje-u privatnom najmu imamo $6,9 \%$ i neznatnih 1,9\% stanova koje možemo prepoznati kao neki od oblika socijalnog najma."

Različiti programi stanogradnje na području Hrvatske sve do konca Drugoga svjetskog rata provođeni su sporadično i simbolično u odnosu na potrebe. Sa sustavnijom izgradnjom stambenog fonda započinje se tijekom 1950-ih godina, da bi se 1960-ih počelo s masovnom izgradnjom stambenih zgrada, odnosno stambenih naselja u cilju osiguranja odgovarajućeg i priuštivog stanovanja uslijed industrijalizacije u grad novopridošlom seoskom stanovništvu. Najznačajniji program stanogradnje u Hrvatskoj do 1991. bila je Društveno

\section{(1)}

Miletić, „U potrazi za drugim prostorom”.

Prema popisu stanovništva iz 20II., u Republici Hrvatskoj postoji

ukupno 2246 9Io stanova, od kojih je I 912 90I za stalno stanovanje.

Od tog je broja I 496558 nastanjeno, tj. upotrebljava se.

„Statistička izvješća I586/2017,", I5.

8

Bobovec, Križ-Šelendić, „Strategija za poticanje ulaganja”, 95.

9

Tijekom šest godina, od 199I. do I997., prodano je 299 I36

društvenih stanova. Od navedenog broja $76 \%$ prodano je nositeljima

stanarskog prava. Bežovan, „Tranzicija u stambenom sektoru”. 10

„Statistička izvješča I586/20I7,”, I8.

11

Rosenfeld, Social Housing in the UNECE Region, $4 \mathrm{I}$. 12

Jukić, Mlinar, Smokvina, Zagreb: Stanovanje u gradu i stambena naselja, 30. 13

Bašić, „Urbanistički standardi planiranja novih stambenih naselja”, 75 . 14

Bobovec, Mlinar, Pozojević, „Programi stanogradnje u

Hrvatskoj", 218 .

15

Bobovec, „Stambeno zbrinjavanje stradalnika Domovinskog rata”, 2. 16

Mlinar, „Zagrebačka stambena naselja”, ı6o.

17

Program stambenog zbrinjavanja stradalnika iz Domovinskog rata provodi se od I997. Najpoznatiji i najuspješniji Program drustveno poticane stanogradnje (POS) provodi se od 200I., a Program stambenog zbrinjavanja povratnika - bivših nositelja stanarskog prava od 2008. Dva su programa regulirana posebnim zakonima Poticanje prodaje stanova provođeno 20I0./20II. i Subvencioniranje i državna jamstva stambenih kredita provođeno 20II./20I2. Program POS kreditiranje obiteljskih kuća provodi se od 20II., a Program $P O S+$ od 20I3. Nakon katastrofalnih poplava u istočnom dijelu Hrvatske 20I4. provodio se Program obnove i saniranja posljedica katastrofe na području Vukovarsko-srijemske županije-obnova zgrada. Bobovec, Mlinar, Pozojević, „Programi stanogradnje u Hrvatskoj“, 218. 18 „Put do najma“. 19 Knifić Schaps, Arhitektonske politike Republike Hrvatske, 28. 
usmjerena stambena izgradnja, tzv. DUSI, uspostavljen sredinom 1970-ih kao alternativa postojećim postavkama urbanističkog planiranja i stanogradnje. ${ }^{12}$ Program stanogradnje DUSI bio je urbanističko-arhitektonski detaljan i sveobuhvatan te usmjerujući, ali ne i obvezujući, odnosno njegova uspješna primjena bila je motivirana kvalitetom programa, a ne primjenom referentnih zakona ili podzakonskih akata. ${ }^{13}$ U Zagrebu su prema DUSI-ju 1970-ih i 1980-ih godina realizirana stambena naselja Dugave, Sloboština, Gajnice, Špansko, Jarun, Ravnice, Klaka i Staglišće. Polazišta i rezultati DUSI-ja bili su kvalitetna osnova i poticaj za pripremu programa stanogradnje u Hrvatskoj nakon osamostaljenja 1991.14

U Domovinskom ratu u Hrvatskoj je od 1991. do 1995. dijelom razoreno približno 590 naselja, odnosno, 160000 stanova ili $11 \%$ stambenog fonda. ${ }^{15}$ Također, oštećen je i znatan dio gospodarskih resursa, što je uzrokovalo spori poratni ekonomski oporavak i stagnaciju u stanogradnji. Nedostatak vizije u području graditeljstva za posljedicu je imao parcijalnu i nekvalitetnu stambenu gradnju privatnih poduzetnika na često neprimjerenim lokacijama. ${ }^{16} \mathrm{U}$ razdoblju od 1991. do 2019. u Hrvatskoj su postupno pripremani, provedeni ili se još provode neki od devet programa koji se odnose na društvenu stanogradnju i osiguranje dostupnosti odgovarajućem stanovanju. ${ }^{17}$ Program društveno poticane stanogradnje, tzv. POS - koji se često krivo poistovjećuje sa socijalnom stambenom izgradnjom, program je subvencioniranog stanovanja osmišljen za kreditno sposobne građane Republike Hrvatske koji svojim redovitim prihodima bez pomoći države i jedinica lokalne samouprave ne mogu riješiti stambeno pitanje na slobodnom tržištu. Programom se mogu koristiti i jedinice lokalne samoupravne i druge pravne osobe sa sjedištem u Hrvatskoj za izgradnju stanova za najam. Nakon globalne ekonomske krize 2008. godine, koja je znatno utjecala i na Hrvatsku, umjesto gradnje novih stanova doneseni su programi za Poticanje prodaje stanova (2010./2011.) i Subvencioniranje i državna jamstva stambenih kredita (2011./ 2012.), koji potiču prodaju i preprodaju postojećega stambenog fonda. Program društveno poticanog najma stanova (PON), uspostavljen 2015., dio je programa POS, pri čemu se izgrađeni stanovi daju u najam, a najmoprimac ima mogućnost prvokupa. Ovakvih je stanova svega 879 u čitavoj Hrvatskoj, tj. svega 10 \% stanova izgrađenih putem POS-a. ${ }^{18}$

Pri formiranju programa POS-a, kao temeljnog programa društveno poticane stanogradnje, ishodišna ideja bila je ne samo afirmirati subvencionirano stanovanje nego, oslanjajući se na iskustva DUSI-ja, započeti s izgradnjom stambene politike socijalnog karaktera, kako bi se u svim segmentima društva, pa tako i tijelima državne uprave i samouprave, neovisno o opcijama koje su na vlasti, formirao i zadržao jasan stav o pravu svakog građana na stanovanje, odnosno o rješavanju stambenog pitanja kao temelja socijalnog mira i napretka društva i države. Ne manje važne bile su kvaliteta i kultura stanovanja, odnosno izgradnja prostora, u cilju njihova unaprjeđenja jer: „Izgrađen prostor treba biti poticajan životni ambijent, a njegova vrsnoća predstavlja osnovu za kvalitetu naših života." ${ }^{19}$ Kao optimalan tip, kako zbog svoje 

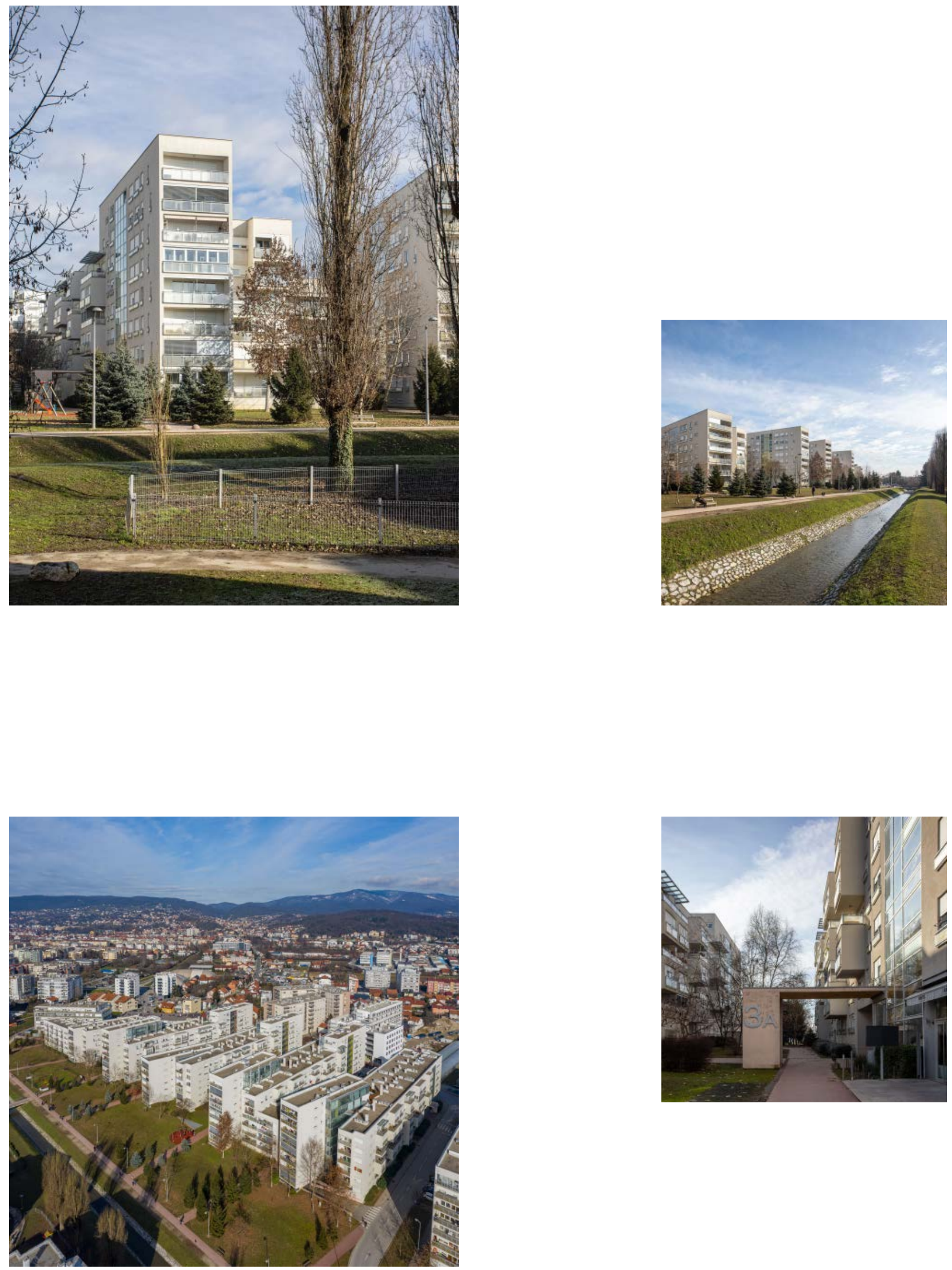


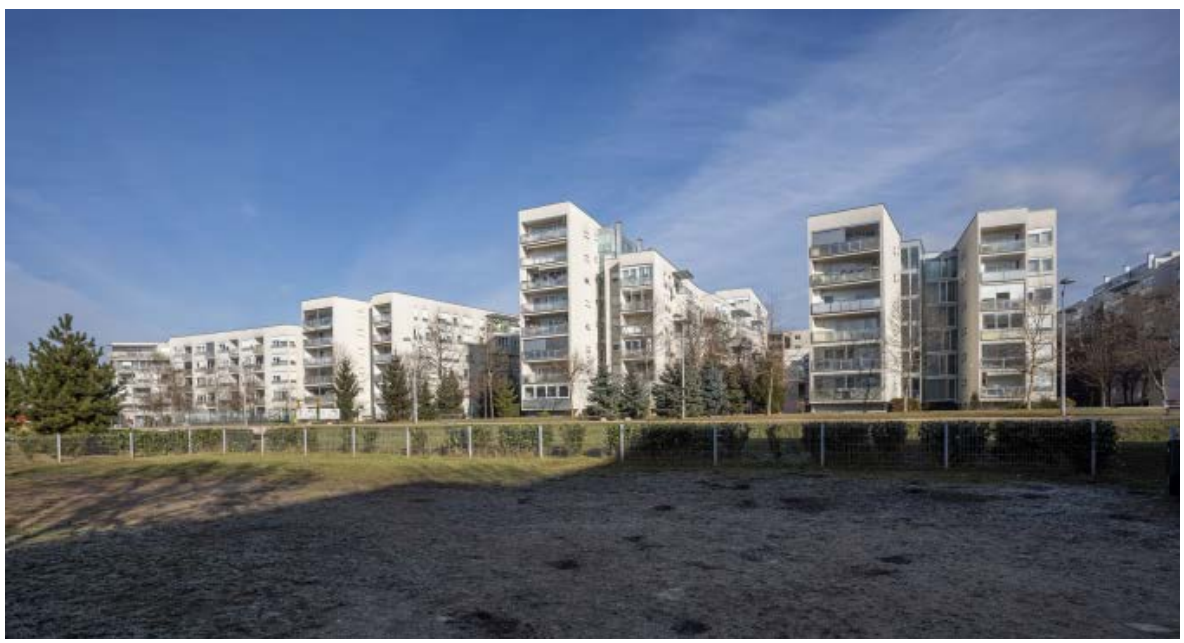

Tržišno motivirana stambena izgradnja Pavlenski put (2006.-2008.) u Zagrebu, 2020. Foto:

Paolo Mofardin / Commercial housing development Pavlenski put (2006-2008) in Zagreb, 2020.

Photo: Paolo Mofardin

$\leftarrow \uparrow \downarrow$
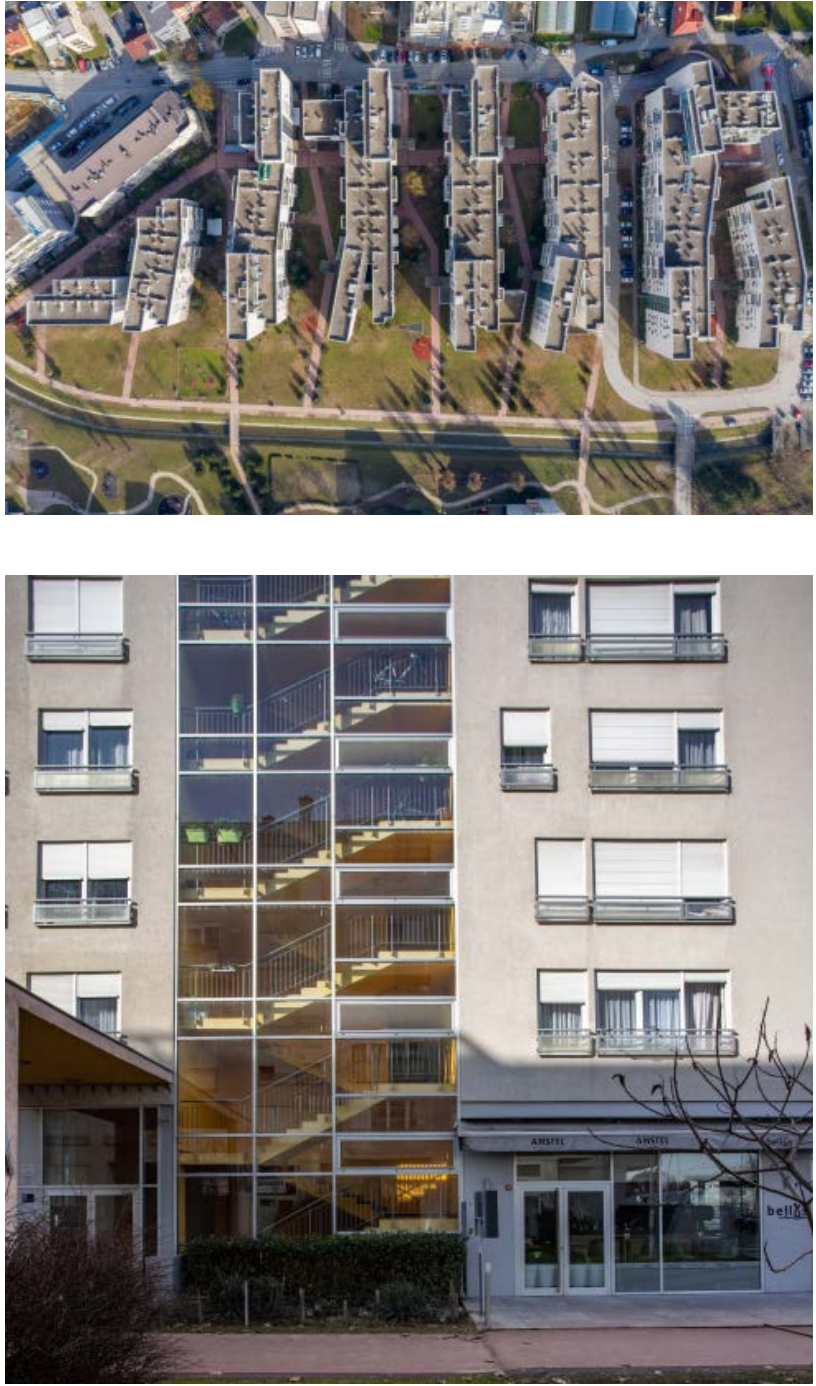
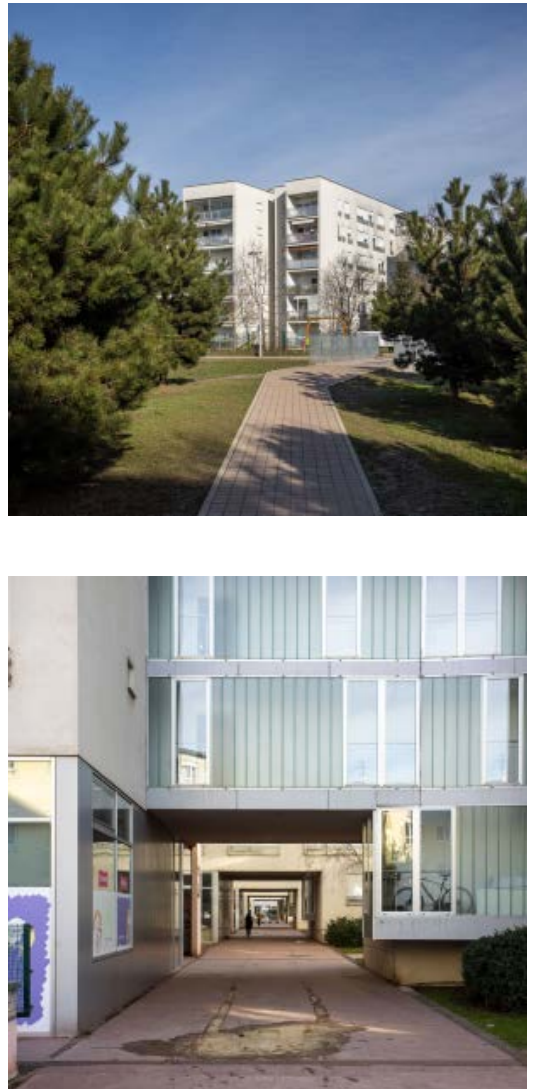
ekonomičnosti tako i zbog socijalnog povezivanja i kohezije zajednice, odabrano je kolektivno stanovanje, tj. stanovanje u stambenim zgradama. Među ciljevima je POS-a i jednostavnija kupnja stana za krajnje korisnike, odnosno obitelji i pojedince.

\section{PROVEDBA POS - a PUTEM ARHITEKTONSKIH NATJEČAJA}

Svi elementi provedbe POS-a temelje se na odredbama Zakona o društveno poticanoj stanogradnji donesenog $2001 .^{20}$ Pravo kupnje POS-ovih stanova imaju svi kreditno sposobni kandidati, isključivo s utvrđenih konačnih lista reda prvenstva jedinica lokalne samouprave, koje osiguravaju zemljišta i snose troškove opremanja zemljišta komunalnom infrastrukturom. Republika Hrvatska pokriva troškove izgradnje u dijelu koji odgovara visini od $25 \%$ etalonske cijene građenja po $\mathrm{m}^{2}$ korisne površine stana. ${ }^{21} \mathrm{Na}$ temelju utvrđenih stambenih potreba na određenom području, izrađuje se program definiran brojem i veličinom stanova za svaku pojedinačnu stambenu zgradu. Ambicija je bila da se ostvare najvrsniji rezultati kroz provođenje arhitektonskih natječaja „na kojima je arhitektima bio izazov zadovoljiti natječajnim programom definiranu kombinaciju veličine i broja pojedinih stanova” ${ }^{22}$ na različito zahtjevnim parcelama koje su za provedbu POS-a ustupale jedinice lokalne samouprave. Uz kvalitetan program i raspis natječaja za vrsnoću projekata, bila je presudna iznimno visoka motiviranost natjecatelja nakon razdoblja stagnacije znatnije arhitektonske produkcije 1990-ih, tj. izostanka prigoda za ravnopravnu arhitektonsku kompeticiju. Za POS se često navodi da je „probudio uspavano tranzicijsko društvo po pitanjima stanovanja” i putem arhitektonskih i urbanističkih natječaja uveo novu generaciju mladih arhitekata, danas etabliranih projektanata, na arhitektonsku scenu. ${ }^{23}$ Njihovo obilježje bila je individualnost i različit pristup rješavanju zadataka, tako da ih je nemoguće svrstati u određene pravce, jer upravo je ono što ih čini uspješnim njihova različitost, koju ovdje možemo čitati kao poveznicu. Ovoj skupini arhitekata pripadaju autori i autorske grupe koje možemo nazvati „generacijom koja je obilježila početak 21. stoljeća”, koja je imala sreću započeti profesionalnu karijeru u trenutku kada se u Hrvatskoj broj natječaja, investitora i mogućnosti dokazivanja talenta otvorio u velikom obimu.

Po dovršetku natječaja i odabiru, s prvonagrađenim autorom zaključivao se ugovor za izradu projektne dokumentacije. U postupku izrade projektne dokumentacije projektantima je u početku, od 2001. do 2004., bio na raspolaganju Privremeni pravilnik za Program društveno poticane stanogradnje. Privremeni pravilnik definirao je obvezne prostorije stana u relaciji s brojem soba i minimalnu veličinu dnevnog boravka, obvezno parkirališno mjesto, dimenzije hodnika i stubišta itd. Kako bi se u konačnici osigurala što kvalitetnija projektna dokumentacija, proces projektiranja stalno su pratili i korigirali stručni revidenti za arhitekturu, koji su kontrolirali i usmjeravali projektanta kako bi projektna dokumentacija bila usklađena s postavljenim zahtjevima lokacije i privremenim pravilnikom. ${ }^{24}$
20

„Zakon o društveno poticanoj stanogradnji”. 21

Etalonsku cijenu građenja utvrđuje jednom godišnje ministar nadležan za graditeljstvo, gdje cijena građenja podrazumijeva sve troškove izgradnje: projektiranje, građenje, nadzor i dr., uključujući i porez na dodanu vrijednost. Troškovi koji se odnose na zemljište, uređenje komunalne infrastrukture i priključke na infrastrukturu nisu uključeni u etalonsku cijenu građenja. 22

Bobovec, Mlinar, „Program društveno poticane stanogradnje u Hrvatskoj”, I45. 23

Jošić, „Europan vs. POS”, Io6.

24

Revizija je bila povjerena nastavnicima Arhitektonskog fakulteta Sveučilišta u Zagrebu.

25

Prvi stanovnici naselja Špansko-Oranice uselili su se već 2005. (Mlinar, „Zagrebačka stambena naselja”, I60). 26

Najveći uspjeh na natječajima za pojedinačne zgrade polučila je Sanja Filep ostvarivši čak dvije prve i dvije druge nagrade. Ostale nagrade i realizacije dobili su Helena Knifić Schaps i Mario Volović, nadalje Goran Rako i Nataša Jakšić te Toni Borković. 27

Bobovec, Mlinar, „Program društveno poticane stanogradnje”, I5O. 28

Mlinar, „Zagrebačka stambena naselja”, I6I-I62. 29

Bobovec, Mlinar, „Program društveno poticane stanogradnje u Hrvatskoj", I5I.

30

Isto, I47-I49. 
Arhitektura POS-a standardom ne odudara od one producirane za tržište, već upravo suprotno-nameće joj više standarde po nižim cijenama, čime POS postaje korektiv tržišta nekretnina temeljenog na zakonu ponude i potražnje. U programu POS-a planiraju se i realiziraju i stambena naselja s pratećim sadržajima, ukazujući na potrebu djelovanja u urbanističkom, a ne samo arhitektonskom mjerilu. Naselje Špansko-Oranice upravo je primjer rutinerskog urbanizma realiziranog na temelju nagrađenog natječajnog rada Zorana Hebara iz Urbanističkog zavoda grada Zagreba, odnosno detaljnog plana uređenja stambenog naselja usvojenog 2003. ${ }^{25}$ Plan je rezultat državnog, javnog i pozivnog anonimnog natječaja za izradu prostorno-programske studije stambenog naselja raspisanog gotovo istodobno s onim za naselje Novi Jelkovec te natječajima za stambene zgrade u Španskom i na Oporovečkoj cesti. ${ }^{26}$ Oba naselja, ŠpanskoOranice i Novi Jelkovec, planirana su na zemljištu s izravnim pristupom infrastrukturi-bivša vojarna površine 19 hektara i svinjogojska farma u Sesvetama površine 33,2 hektara. Dok je na prvoj lokaciji izgrađeno 27 stambenih i stambeno-poslovnih zgrada s 1423 stana (2004.-2009.) na drugoj ih je izgrađeno dvostruko više - 54 s 2733 stana (građeno od 2007.). ${ }^{27}$ Odmak od shematičnoga ortogonalnog plana u Jelkovcu je učinjen implementiranjem različitih tipova izgradnje, odnosno različitih artificijelno kreiranih ambijenatatzv. „megastruktura”, ,prsti”, ,park-šuma” i „elipsa”. Autori su prvonagrađenoga natječajnog projekta, razrađenog u detaljnom planu uređenja stambenog naselja (2003.), Sanja Gašparović, Darija Maletić Mirko, Nataša Martinčić, Ivan Mlinar, Marija Premužić i Krunoslav Šmit s Arhitektonskog fakulteta Sveučilišta u Zagrebu. ${ }^{28}$ Zanimljivo je da je Novi Jelkovec planiran i projektiran u sklopu provedbe POS-a, ali izgradnju naselja i zgrada te prodaju stanova preuzeo je Grad Zagreb prema takozvanom Zagrebačkom modelu stanogradnje, dok je samo 149 stanova ostalo u Programu društveno poticane stanogradnje. $^{29}$

Iznimno kvalitetan odgovor na natječajne programe raspisane za manje sredine specifičnog ambijenta, odnosno prirodnog krajolika, daju arhitekti mlađe generacije s tek nekoliko godina radnog iskustva-Vesna Mravinac i Dubravka Vranić u Krapini, Iva Letilović i Morana Vlahović u Krapinskim Toplicama te Vladimir Kasun i Ivica Plavec u Delnicama. Na zadanim lokacijama arhitekti istodobno odgovaraju i inventivnošću tipa i oblikovanja kako samog volumena tako i oplošja, interpretirajući i u zgradu ugrađujući lokalne, zatečene vrijednosti. Posebnu važnost temi zajedništva i suživota kroz oblikovanje zajedničkih komunikacija i prostora te samom prostoru stana daju Siniša Justić u Krapini, Dario Gabrić u Zadru i Helena Paver Njirić u Rovinju. Konceptom se izdvajaju zgrade koje su projektirali Robert Jonatan Loher, Petar Mišković i Branimir Rajčić u Đakovu te Marija Burmas i Ivo-Lola Petrić u Vrgorcu. Uz navedene stambene zgrade, treba istaknuti i jedini primjer sklopa od dva stambena niza prizemnih i katnih stambenih jedinica u Đurđevcu Nikole Škarića. ${ }^{30}$ Realizirani projekti pokazuju jasnu osviještenost nove generacije arhitekata, koji njeguju interdisciplinarni pristup, arhitekturu i urbanizam razumiju kao proces te mnogo 

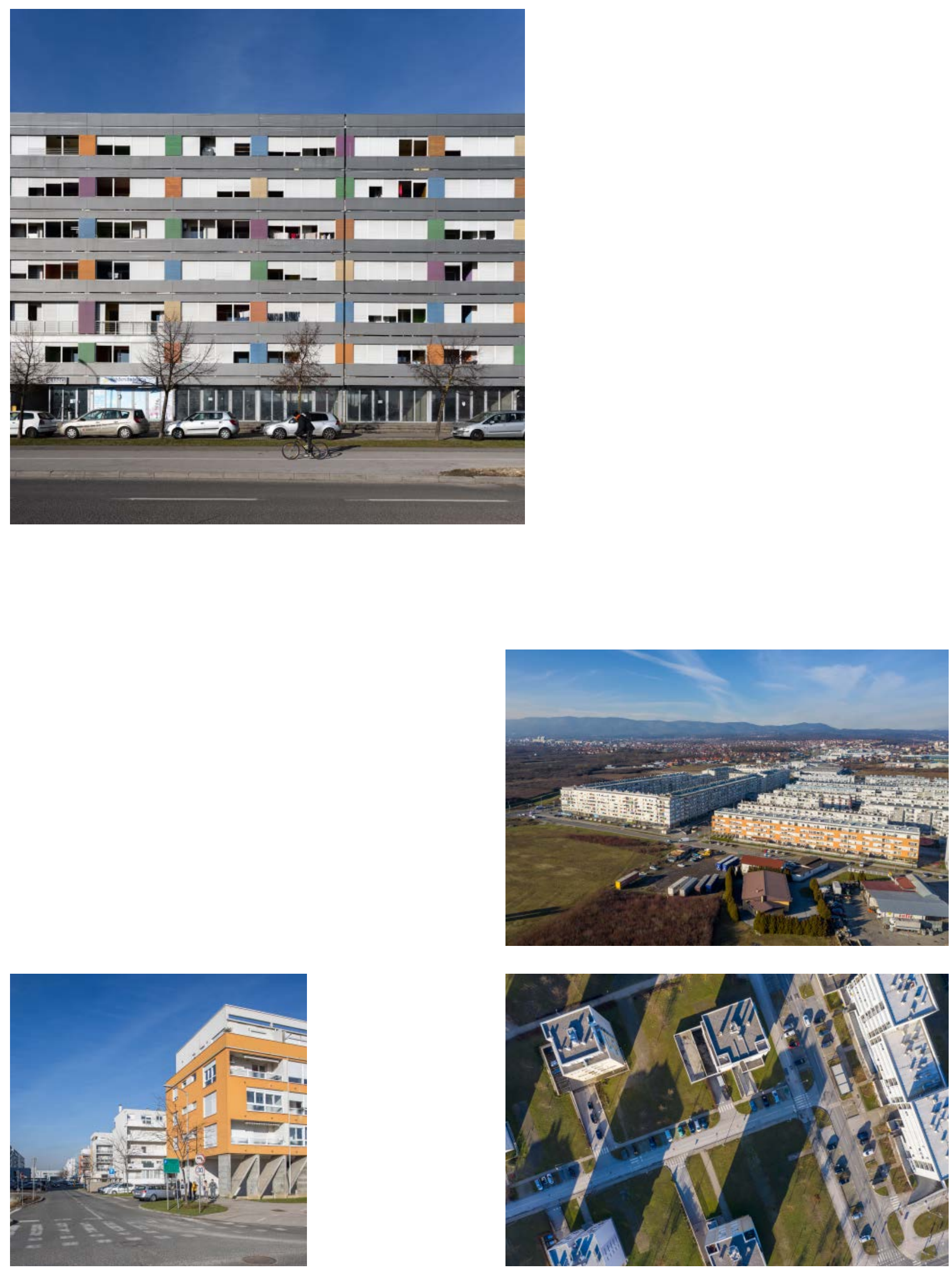

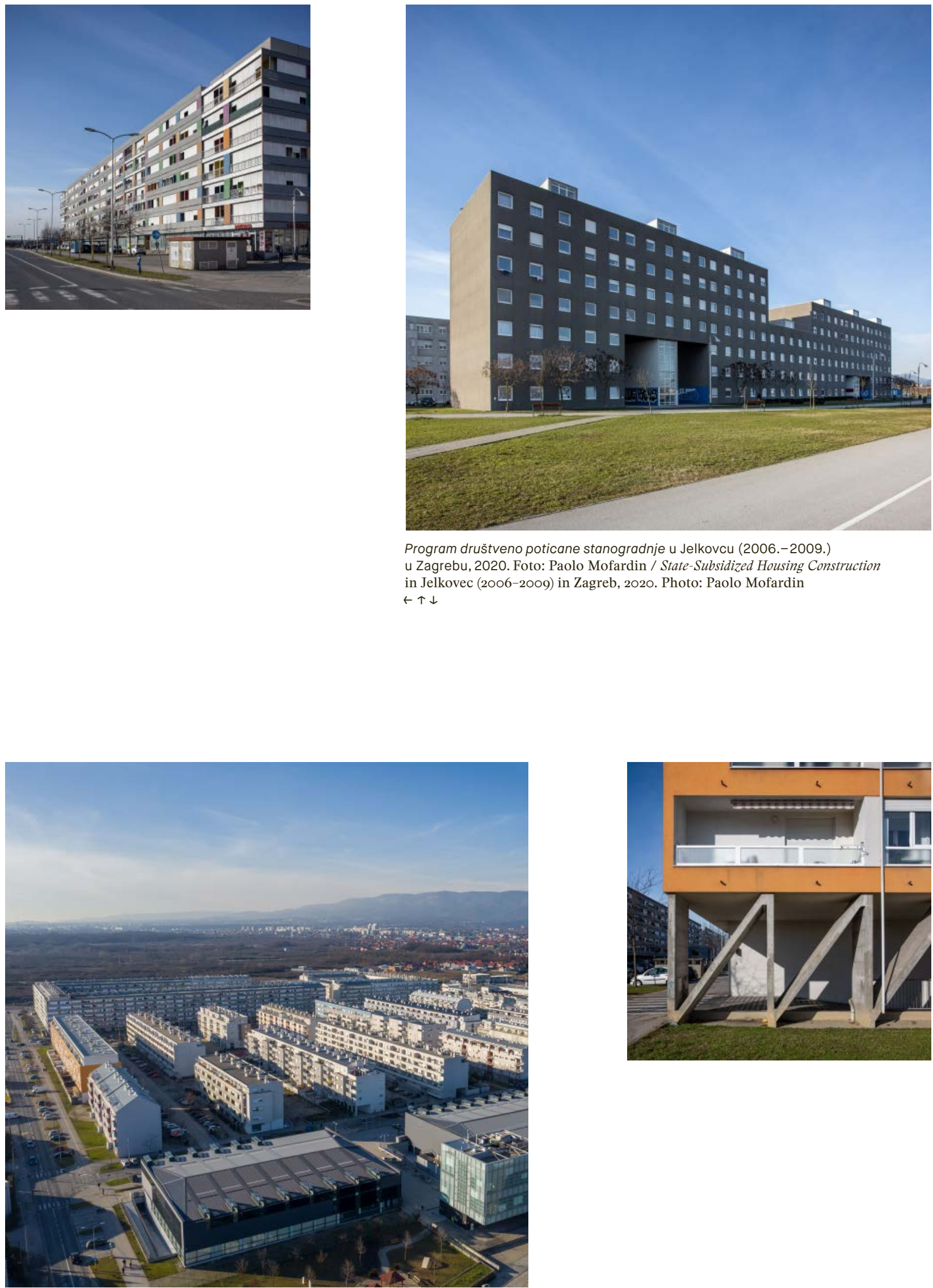
više, u odnosu na prošle generacije, aktivno uključuju buduće korisnike u razvoj projekta. ${ }^{31}$ Naglašena je i svijest da je arhitektura društveno odgovorna disciplina usmjerena prema poboljšanju kvalitete prostora svakodnevice.

U prilog ovoj tvrdnji ide niz domaćih nagrada autorima navedenih zgrada, strukovna nagrada za stambenu arhitekturu Drago Galić Udruženja hrvatskih arhitekata i godišnja državna nagrada Vladimir Nazor za najbolja umjetnička ostvarenja u kategoriji Arhitektura i urbanizam, ali i međunarodnih. ${ }^{32}$ Grandiozan početak niza bila je dodjela dvije jednakovrijedne nagrade Drago Galić za 2003. godinu arhitektonskom triju Loher-Mišković-Rajčić i dvojcu Letilović-Vlahović. Zahvaljujući stambenoj zgradi u Krapinskim Toplicama, Letilović i Vlahović postale su i prvi ženski arhitektonski par kojem je dodijeljena državna nagrada Vladimir Nazor za najbolje arhitektonsko ostvarenje, slovenska nagrada Piranesi, priznanje na međunarodnom natječaju „Das Erste Haus” u Njemačkoj i priznanje Silver Plate u Italiji. Već sljedeće godine, 2004., republičku nagradu Vladimir Nazor dobivaju Ivana Ergić, Vanja Ilić i Vesna Milutin za POS-ovu zgradu na Cresu. ${ }^{33}$ Brojne nagrade potvrđuju značaj doprinosa POS-a hrvatskoj arhitekturi početka 21. stoljeća koji je danas neupitan. ${ }^{34}$

\section{PROVEDBA PROGRAMA POS}

OD 2004. GODINE

Pravilnik minimalnih tehničkih uvjeta za projektiranje i gradnju stanova iz programa društveno poticane stanogradnje, i danas jedini važeći dokument koji propisuje i strukturira sve elemente stana, usvojen je 2004. Uporaba Pravilnika prerasla je POS i ustalila se kao primjenjivi okvir u stanogradnji kojim su propisani i strukturirani svi elementi stana-definirani ukupna površina stana, površine i minimalne dimenzije prostorija, njihove funkcionalne veze i higijenski standard. Sastavni je dio i tablica s relacijom između ukupne kvadrature stana i broja soba. U odnosu na Privremeni pravilnik, kvaliteta stanovanja umanjena je izbacivanjem obveznog položaja kuhinje na pročelju, odnosno povezivanjem kuhinje s pročeljem preko blagovanja, kao i omogućenom najlošijom jednostranom orijentacijom stana na sjever.

Tijekom 2004. odustalo se i od provođenja arhitektonskih natječaja i ugovaranje arhitektonskog projekta nadalje se vršilo po principu javne nabave, koja, nažalost, nije prepoznala vrsnoću projekta, već samo cijenu. ${ }^{35}$ Iznimka je provedeni urbanističko-arhitektonski natječaj za naselje Sopnica jug u Zagrebu iz 2007., koji je ostao na razini projekta. ${ }^{36}$ Razlika $\mathrm{u}$ arhitektonskoj vrsnoći izgrađenih zgrada vidljiva je kroz usporedbu zgrada realiziranih između 2004. i 2007.-među kojima je i dalje znatan broj onih koje su projektirane, a onda i izvedene na temelju natječaja provedenih od 2001. do 2003. -koje osvajaju strukovne nagrade, dok se u nastavku provedbe POS-a broj nagrada znatno smanjuje.

Od ideje da POS bude poticatelj izvrsnosti-poticaj i motiv za podizanje općeg standarda arhitektonske produkcije i kreiranja priuštivog i kvalitetnog stana unutar dobro
31 Bobovec, Korlaet, „Analiza rezultata Europanovih natječaja”, 576. 32

Nagradu za stambenu arhitekturu Drago Galić dobili su i Helena Paver Njirić 2005. te Marija Burmas i Ivo-Lola Petrić 20ıo. Vladimir Kasun i Ivica Plavec također su dobili priznanje Piranesi 2004. Bobovec, Mlinar, „Program društveno poticane stanogradnje u Hrvatskoj”, I47-I49. 33

Trio Ergić, Ilić i Milutin dobio je, poput Letilović i Vlahović, i nagradu Piranesi 2004. i Silver Plate 2005. Bobovec, Mlinar, „Program društveno poticane stanogradnje u Hrvatskoj", I47-I49. 34 Galijašević, Jošić, Vlahović, Zgrade društveno poticane stanogradnje, I69-170. 35

Od 2000. do 2003. izgrađeno je 906 stanova u 3I stambenoj zgradi. Od 2004. do 2007. izgrađena su 3634 stana u II3 stambenih zgrada. Bobovec, Mlinar, „Program društveno poticane stanogradnje”, 154. 36

„Natječaj za idejno urbanističko-arhitektonsko rješenje”.

37

Bobovec, Mlinar, Pozojević, „Programi stanogradnje u Hrvatskoj”, 220-223. 38

Kolešnik, Između Istoka i Zapada, 69. 
planiranog stambenog susjedstva, Program je prošao nekoliko faza, a paralelno su razvijani i drugi programi subvencioniranog stanovanja. ${ }^{37}$ Razlike u ideji i pristupu programiranju, planiranju, projektiranju i izgradnji POS-a, naspram isključivo tržišnog pristupa izgradnje stanova s gotovo maksimalnom iskoristivošću zemljišta dopuštenom Generalnim urbanističkim planom, vidljive su na zagrebačkom primjeru POS-ova stambenog naselja Špansko-Oranice i susjednog stambenog sklopa Pavlenski put, koji je projektiran i izgrađen na tržišnim osnovama.

Kako bi se POS ponovno odmaknuo od trenutačnih trendova, tj. prosječnosti, važno je preispitati cijelu ideju POS-a, odnosno vratiti ga na početne postavke-izgradnju kvalitetnog i dostupnog stana u kvalitetnom i poticajnom životnom okruženju rukovodeći se svim relevantnim parametrima-sociološkim, ekonomskim i klimatskim - te samom lokacijom i navikama lokalnog stanovništva, pri čemu evidentno nije dostatno samo pratiti postojeći zakonodavni okvir, već treba sustavno raditi i na donošenju novih smjernica i standarda, pogotovo kada je riječ o urbanističkom planiranju. Za promišljanje nadgradnje stanovanja, zgrada društvenog standarda, javnih i zelenih površina te u konačnici vizualnog identiteta potrebni su projekti veći od mjerila jedne parcele ili nekoliko zgrada, koji uz stanove za poznate kupce trebaju uključiti i veći broj stanova za najam, ali i nove oblike stanovanja za druge društveno osjetljive skupine stanovnika, primjerice umirovljenike. I tu dolazimo do države i jedinica lokalne samouprave, odnosno do regulatora i pokretača strukturiranja svih pomaka koji su se događali ili se imaju dogoditi u ovom segmentu. Ponuđena rješenja koja su godinama stvarana kroz POS danas predstavljaju stambeni fond koji je u neposrednom korištenju, a rezultat su znanja urbanista i arhitekata koji su svoja autorska djela uklapali u postojeće urbane cjeline ili stvarali potpuno nove ambijente i čitava naselja. Rezultati ostvareni kroz POS u njegovu inicijalnom razdoblju dobar su temelj za poboljšanje korištenja prostorom svakodnevice. Analiza i valorizacija dobivenih podataka može poslužiti za pravilno usmjeravanje djelovanja i stvaranja stambene politike, preporuka, novih pravila i novih načina strukturiranja nužne stambene strategije i pratećih stambenih programa.

\section{ZAKLJUČAK}

Novo stoljeće donijelo je nove odnose ne samo u društvu nego i u načinu razmišljanja i pristupa stambenoj arhitekturi. Socijalni aspekti, stvaranje fizičkih i virtualnih susjedstava, dijeljenje prostora i infrastrukture, preklapanje različitih mjerila od stana i susjedstva do naselja, područja i regije, postaju nezaobilazni elementi novog promišljanja zajedničkog prostora svakodnevnog življenja. Njihovo kreiranje nužno je, uvijek i svagdje, usko vezano uz politiku, koja ima ili nema ideju o vrijednosti i značaju prostora o kojem odlučuje kao zakonodavac i investitor. ${ }^{38}$ Odgovornost za rješavanje stambenih problema, tj. izgradnju novih stanova, nije samo na državi. Na njoj je da stvori provedbeni okvir, mogućnost, dok je primarna odgovornost na jedinicama lokalne 

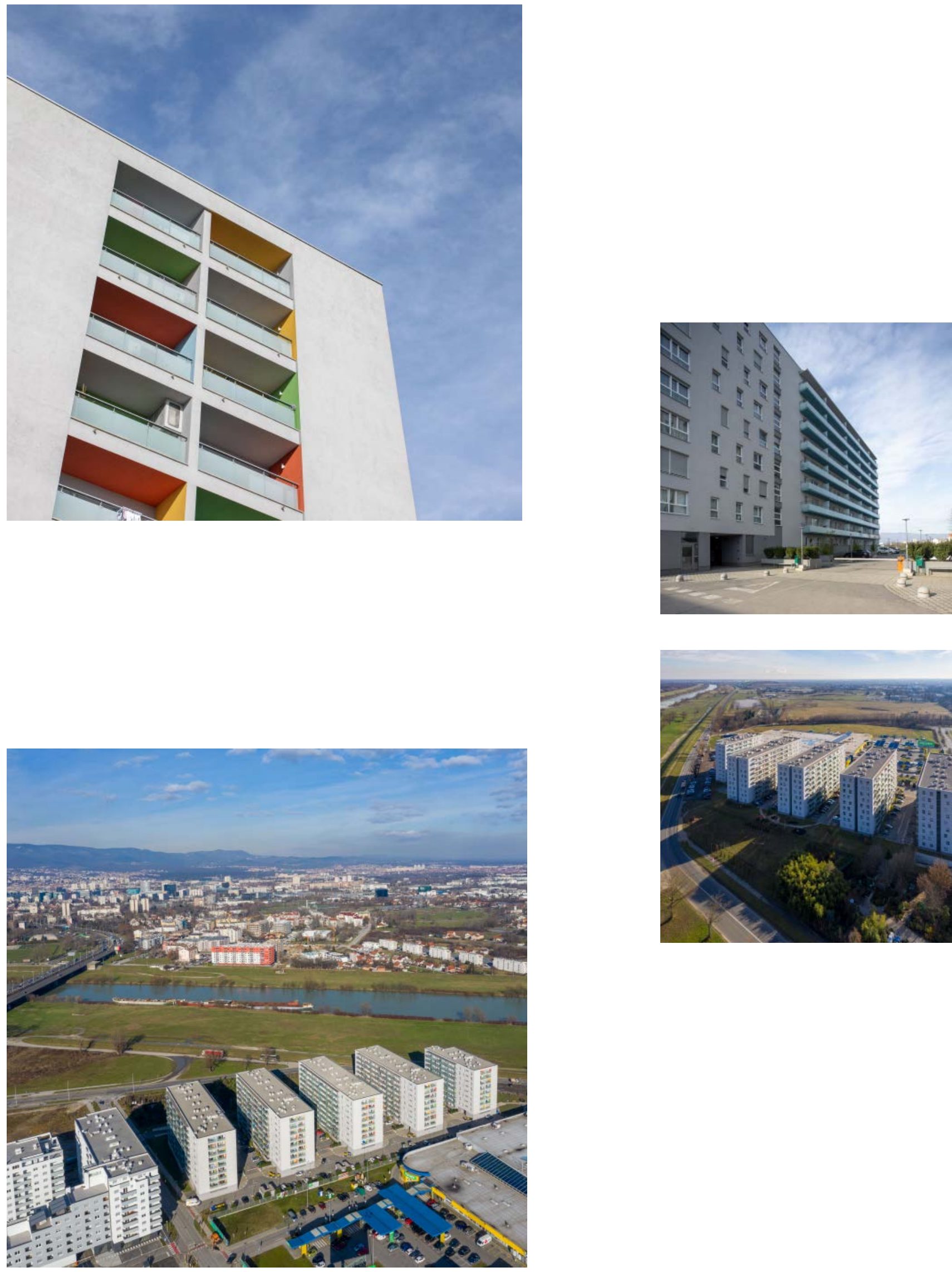


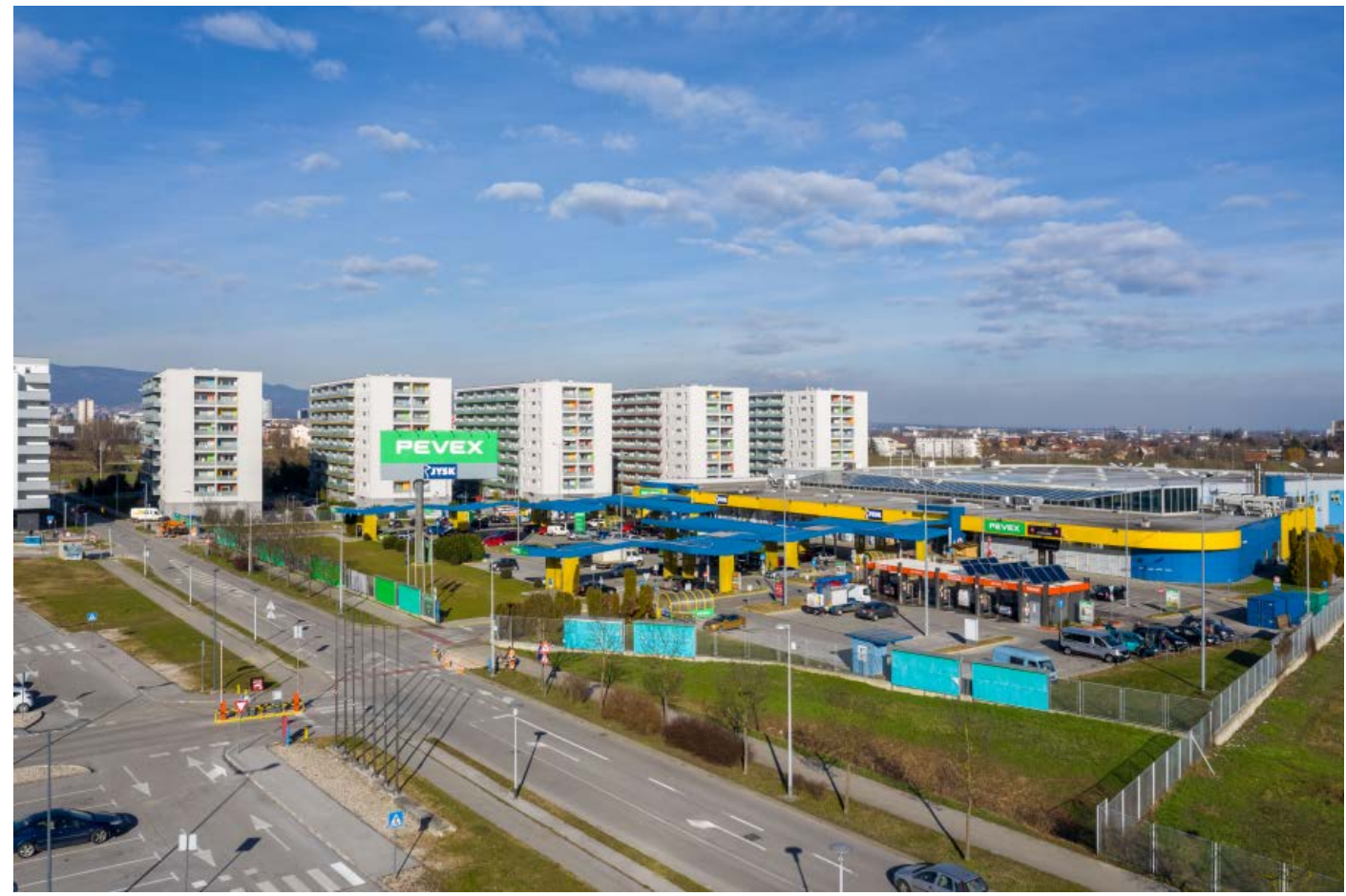

Program društveno poticane stanogradnje (POS) u Zapruđu (2014.-2016.) u Zagrebu, 2020. Foto: Paolo Mofardin / State-Subsidized Housing Construction in Zapruđe (20I4-2016) in Zagreb, 2020. Photo: Paolo Mofardin $\leftarrow \uparrow \downarrow$
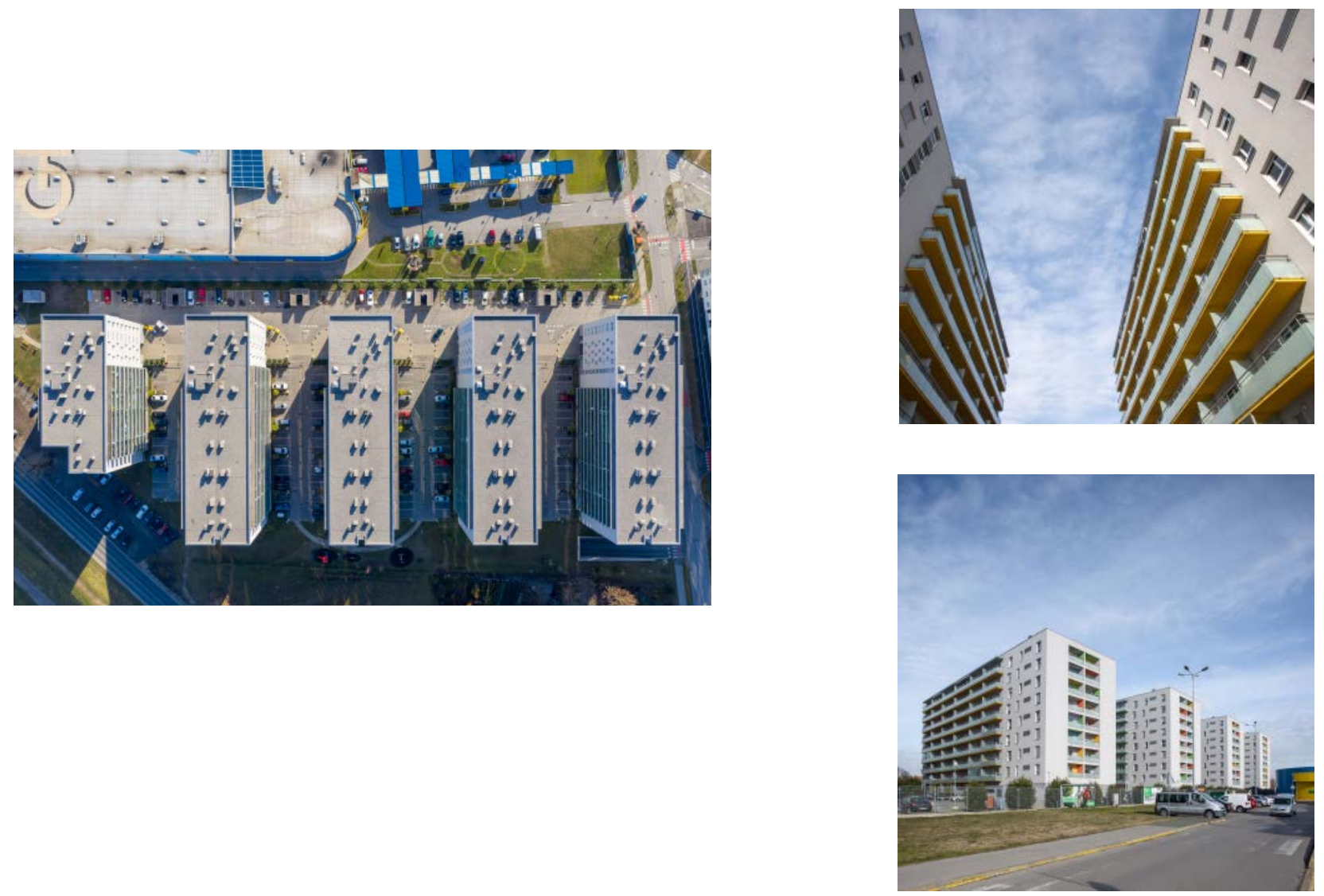
samouprave-budući da je mjesto stanovanja direktno povezano s lokalnim zajednicama. Iz istog razloga one bi trebale biti najzainteresiranije za optimalno iskorištavanje svih strukovnih potencijala u cilju ostvarivanja arhitektonske vrsnoće.

Program društveno poticane stambene izgradnje, tj. POS, upravo je to, program s definiranim zakonskim i financijskim okvirom i poticajnim učinkom na gospodarstvo, koji je hrvatskim građanima trebao omogućiti priuštiv stan, ali i unaprijediti hrvatsku arhitekturu na početku novoga, 21. stoljeća. Promjene nastale tijekom dva desetljeća provođenja POS-a potrebno je revidirati u kontekstu aktualnog društvenog trenutka koji ukazuje na potrebu osmišljavanja novih programa i donošenja Stambene strategije usklađene s drugim programskim i strateškim dokumentima, ${ }^{39}$ a u prvom redu gospodarskima i socijalnima, poput Programa provedbe Strategije borbe protiv siromaštva i socijalne isključenosti u Republici Hrvatskoj (2014.-2020.). ${ }^{40}$ U stvaranju novoga zakonskog i financijskog okvira novih programa posebnu pažnju treba posvetiti financiranju kroz partnerstvo javnog i privatnog sektora, odnosno negospodarskih i gospodarskih organizacija. Tu je i moguća reafirmacija zadrugarstva, odnosno aktivnog participiranja investitora/dioničara s jedne strane i korisnika stambenih zgrada za najam. Povratak na osnovna ishodišta koja su u POS uvela projektiranje stambenih zgrada i stambenih naselja uz provođenje urbanističko-arhitektonskih i arhitektonskih natječaja dugoročno mogu donijeti povećanu kvalitetu života u izgrađenim zgradama i naseljima, a arhitektonska struka kroz moguću kreativnu kompetitivnost ostvarenje vrsnih djela u području stambene arhitekture.

„Strategija prostornog razvoja Republike Hrvatske” donesena za razdoblje do 2030. pristupa „stanovanju kao temeljnoj funkciji grada kojoj treba posvetiti posebnu pažnju na nacionalnoj i lokalnoj razini utvrđivanjem odgovarajućih mjera za ostvarivanje prava na priuštivo i kvalitetno stanovanje”. Marohnić-Kuzmanović, Matković, Korlaet, Strategija prostornog razvoja Republike Hrvatske, 124. 40

„Stambene financijske institucije u razvijenim zemljama imaju dugogodišnju tradiciju i u svom su razvoju doživjele različite promjene. One su kralježnica stambenih sustava.” Bežovan, „Stanovanje i stambeni sustavi u zapadnim zemljama". 


\section{LITERATURA / BIBLIOGRAPHY}

Bašić, Silvio. „Urbanistički standardi planiranja novih stambenih naselja”. Doktorska disertacija, Arhitektonski fakultet Sveučilišta u Zagrebu, 2013.

Bobovec, Borka, Korlaet, Luka. „Analiza rezultata Europanovih natječaja provedenih na lokacijama u Hrvatskoj-Uloga Europana u novom poimanju grada”, 556-579. U: Europan Hrvatska 1992.-2017., ur. Helena Knifić Schaps, Vladimir Mattioni. Zagreb: UPI-2M PLUS, 2018.

Bobovec, Borka. „Stambeno zbrinjavanje stradalnika Domovinskog rata, metode vođenja velikog investicijsko-arhitektonskog projekta”. Magistarski rad, Arhitektonski fakultet Sveučilišta u Zagrebu, 2000.

Bobovec, Borka, Križ-Šelendić, Irena. „Strategija za poticanje ulaganja u obnovu nacionalnog fonda zgrada", 93-104. U: Izazovi u graditeljstvu 2, ur. Stjepan Lakušić. Zagreb: Hrvatski savez građevinskih inženjera, 2014.

Bobovec, Borka, Mlinar, Ivan. „Program društveno poticane stanogradnje u Hrvatskoj”. Prostor 21, br. 45 (2013): 140-157.

Bobovec, Borka, Mlinar, Ivan, Pozojević, Andriana. „Programi stanogradnje u Hrvatskoj od 1991. do 2016. godine”. Prostor 24, br. 52 (2016): 216-227.

Galijašević, Teufik, Jošić, Mladen, Vlahović, Dragomir. Zgrade društveno poticane stanogradnje. Zagreb: Arhitektonski fakultet Sveučilišta u Zagrebu, 2006.

Jošić, Mladen. „Europan vs. POS”. Arhitektura 53, br. 216 (2004): 106-109.

Jukić, Tihomir, Mlinar, Ivan, Smokvina, Marina. Zagreb: Stanovanje u gradu i stambena naselja. Zagreb: Arhitektonski fakultet Sveučilišta u Zagrebu, Zavod za urbanizam, prostorno planiranje i pejzažnu arhitekturu-Grad Zagreb, Gradski ured za strategijsko planiranje i razvoj Grada, 2011.

Knifić Schaps, Helena ur. Arhitektonske politike Republike Hrvatske 2013.-2020. ApolitikA: Nacionalne smjernice za vrsnoću i kulturu gradenja. Zagreb: Hrvatska komora arhitekata-Ministarstvo graditeljstva i prostornoga uređenja, 2013.

Kolešnik, Ljiljana. Između Istoka i Zapada: hrvatska umjetnost i likovna kritika 50-tih godina. Zagreb: Institut za povijest umjetnosti, Zagreb, 2006.

Mlinar, Ivan. „Zagrebačka stambena naselja nakon 2000. godine - Natječaji i realizacije”. Prostor 17, br. 35 (2009): 116-125.

Rosenfeld, Orna. Social Housing in the UNECE Region, Models, Trends and Challenges. Geneva: United Nations Economic Commission for Europe, 2015

Marohnić-Kuzmanović, Vesna, Matković, Irena, Korlaet, Ariana ur. Strategija prostornog razvoja Republike Hrvatske. Zagreb: Hrvatski zavod za prostorni razvoj, 2017.

„Zakon o društveno poticanoj stanogradnji”. Narodne novine, 11. prosinca 2001., 4016-4020.

\section{MREŽNE STRANICE / INTERNET SOURCES}

Bežovan, Gojko. „Stanovanje i stambeni sustavi u zapadnim zemljama". Travanj 1999. https://hrcak.srce.hr/file/47225 (pristupljeno 13. listopada 2020.).

Bežovan, Gojko. „Tranzicija u stambenom sektoru i strateške točke razvoja stambene politike u Hrvatskoj”. Ožujak 1998. http:// www.rsp.hr/ojs2/index.php/rsp/article/viewFile/355/862 (pristupljeno 13. listopada 2020.).

„Natječaj za idejno urbanističko-arhitektonsko rješenje stambenog naselja Sopnica jug u Zagrebu". Društvo arhitekata Zagreba. http://www.d-a-z.hr/hr/natjecaji/rezultati/natjecaj-za-idejnourbanisticko-arhitektonsko-rjesenje-stambenog-naselja-sopnicajug,-u-zagrebu,53.html (pristupljeno 5. listopada 2020.).

„POS ide dalje, do 2021. godine tisuću novih stanova”. Republika Hrvatska, Ministarstvo prostornoga uređenja, graditeljstva i državne imovine. https://mgipu.gov.hr/vijesti/pos-ide-dalje-do-2021-godinetisucu-novih-stanova/9293 (pristupljeno 13. listopada 2020.)

„POS-Program poticane stanogradnje”. Republika Hrvatska, Ministarstvo prostornoga uređenja, graditeljstva i državne imovine. https://mgipu.gov.hr/o-ministarstvu-15/djelokrug/stanovanje8130/pos-program-poticane-stanogradnje/8275 (pristupljeno 5. listopada 2020.).

"Statistička izvješća 1586/2017, Popis stanovništva, kućanstava i stanova 2011." Državni zavod za statistiku. https://www.dzs.hr/Hrv_ Eng/publication/2016/SI-1586.pdf (pristupljeno 13. listopada 2020.).

„Strategija borbe protiv siromaštva i socijalne isključenosti u Republici Hrvatskoj (2014.-2020.)". Ožujak 2014. https://vlada. gov.hr/UserDocsImages/ZPPI/Strategije/Strategija\%20borbe\%20 protiv\%20siroma\%C5\%A1tva.pdf (pristupljeno 5. listopada 2020.).

"Put do najma". Agencija za pravni promet i posredovanje nekretninama. http://apn.hr/najam-stanova-i-garaza/put-do-najma (pristupljeno 19. prosinca 2020.)

„Smjernice i kriteriji za arhitektonsku vrsnoću građenja”. Veljača 2011. https://mgipu.gov.hr/UserDocsImages//dokumenti/Prostorno/ ApolitikA//Smjernice_i_kriteriji_za_arhitektonsku_vrsnocu_ gradenja.pdf (pristupljeno 12. siječnja 2021.).

"Arhitektonske politike Republike Hrvatske, 2013.-2020., Nacionalne smjernice za vrsnoću i kulturu građenja”. Studeni 2012. https://mgipu.gov.hr/UserDocsImages//dokumenti/Prostorno/ ApolitikA//ApolitikA_2013-2020.pdf (pristupljeno 12. siječnja 2021.).

Miletić, Geran-Marko. „U potrazi za drugim prostorom: sociologijski aspekti sekundarnog stanovanja u Hrvatskoj”. 2011. https://www.bib. irb.hr/530926 (pristupljeno 12. sijec̆nja 2021.). 